\title{
Text Construction of Corruption News in Newspapers in The Perspective of Van Dijk Critical Discourse Analysis
}

\author{
Hari Bakti Mardikantoro', Muhammad Badrus Siroj ${ }^{2}$, Esti Sudi Utami ${ }^{3}$ \\ \{haribaktim@mail.unnes.ac.id ${ }^{1}$; badrussiroj@mail.unnes.ac.id ${ }^{2}$; \\ esti.sudiutami@mail.unnes.ac.id ${ }^{3}$ \} \\ ${ }^{1,2,3}$ Faculty of Languages and Arts, Universitas Negeri Semarang, Indonesia
}

\begin{abstract}
This research is aimed at determining the social cognition of news texts in newspapers. This research employed a descriptive qualitative approach with the analysis of Teun van Dijk's critical discourse, precisely the dimension of social cognition. The research data were collected through the method of simak (observe) and the technique of catat (noting). The results showed that in terms of social cognition, the role of editors was crucial in a newspaper report. Each newspaper has its plot and way of producing corruption news, depending on the ideology and the motto of the newspaper. News construction or commonly known as framing a news text, is a privilege that is owned by each mass media. As a result, the construction of news from Suara Merdeka, Republika, Kompas, and Jawa Pos media has some differences, although it does not rule out some similarities.
\end{abstract}

Keywords: news text, critical discourse analysis, van Dijk

\section{Introduction}

Nowadays, in the industrial era 4.0, information has become an economic, social, and political commodity that people continue to hunt. Hence, the premise 'information is power' applies. Because of the importance of information, the newspaper, which contains a lot of information, certainly gets more interest from the reader. This is proved by the data from Subrata [1] that daily newspapers turn out to be the most popular among readers compared to other types of newspapers. Daily newspapers contain a lot of information and, at the same time, emphasize their novelties.

The community still needs print newspaper or print media amid the proliferation of social media and digital media. While changing trends in media consumption patterns in Indonesia, which tend to start shifting to the digital medium, print media are demanded to be more creative in packaging content to be presented to readers so that print media can be an alternative against hoax information. In print media, every day, we are treated with a variety of issues such as politics, economics, socio-cultural society, to entertainment following the orientation of the media [2].

News that often appears on the pages of newspapers is the news of corruption. Corruption is one of the biggest problems facing developing countries today, including Indonesia. Although it is said that eradication has increased in the last three years, there are no convincing signs that this problem can be resolved immediately. Indonesia remains the country with the highest level of corruption throughout the world. Eradicating corruption is not easy because it has become a deeply entrenched culture at all levels of society. However, 
various eradication continues to be done in stages. If it cannot be completely eliminated, at least it can be reduced.

The results of the monitoring of Kompas, Republika, Indopos, Koran Tempo, Media Indonesia, and Seputar Indonesia newspapers in 2011, as many as 429 headlines, raised the issue of corruption. A year after that, the number increased to 433 headlines and rose to 491 headlines in 2013. The spotlight of the national newspapers is in line with the findings of Indonesia Corruption Watch during January-July 2014. The number of corruption cases that occurred in Indonesia reached 308 cases, an increase of 15 cases compared to semester I-2013. Law enforcement efforts are not lacking, especially done by the Corruption Eradication Commission (KPK), which reveals various corruption cases. However, there are still many corrupting practices that occur. The results of the Kompas Research and Development poll on July 23-25, 2014 emphasized that the message of the latent danger of corruption must be resolved immediately [3].

In this study, the text of corruption reports in newspapers is analyzed by an analysis of critical discourse. Critical discourse analysis is an attempt or process to provide an explanation of a text (social reality) that is studied by a dominant person or group whose tendency has a specific purpose of getting what is desired. This means that in a context, we must be aware of the interests [4]. Additionally, a critical approach places discourse as power [5]. The Renkema [6] views the discourse as a reflection of a power relationship in a society.

This study captured the text of corruption reports in newspapers with an analysis of critical discourse. The critical discourse analysis employed the Teun A. van Dijk model. This approach views cognition as an essential element in the production of discourse. Discourse is not only seen from the structure of discourse but also how the discourse is produced. The process of creating discourse includes a process called social cognition.

\section{Methodology}

The data in this study were collected using the method of simak (observe) [7], which is listening to the use of language in corruption reports in newspapers. The method is followed by the use of rekam (recording) and catat (noting) techniques. The research data were in the form of fragments of corruption news text in the newspaper. Newspapers used as physical data sources are Kompas, Republika, Suara Merdeka, and Jawa Pos. The selection of the newspaper was based on the consideration that Kompas and Republika newspapers represented national newspapers published in the center (Jakarta), while Suara Merdeka and Jawa Pos represented national newspapers published in the regions (Semarang and Surabaya). Data collection was carried out for two months with consideration at that time; it is assumed that the data obtained were sufficient and varied.

Data analysis used van Dijk's critical discourse analysis model. Van Dijk divided the discourse analysis into three dimensions, namely the text dimension, the dimension of social cognition, and the dimension of social context/practice. In this case, data analysis focused on the dimensions of social cognition. Social cognition is used as a dimension to explain how a text is produced and how the mental awareness of journalists produced the text. The cognitive approach was based on the assumption that text has no meaning, but the meaning is given by the language user or the mental awareness process of the reader. 


\section{Finding and Discussion}

In this section, the authors describe the results of the analysis conducted using van Dijk's critical discourse analysis method. The second stage of van Dijk's critical discourse analysis is the level of social cognition (social cognition). The level of social cognition that needs to be considered is how journalists do the news text production process. Analysis of text production is carried out to find out the ideology of the journalist or print media. In this position, it will be seen whether journalists are bound/influenced by working ideologies, social ideologies, such as norms, customs, culture, etc. that reside in the society's cognition.

To search for information or investigate ideology from a media, we need to analyze the process of producing news texts first. The analysis process was carried out with a literature study and interview studies of various activities to the media editorial team. This is because the text constructed and ideology of a media are very closely related.

News construction or commonly known as framing a news text, is a privilege that is owned by each mass media. Therefore, the development of news from Suara Merdeka, Republika, Kompas, and Jawa Pos media has some differences, although it does not rule out some similarities. The emphasis on several aspects can influence and sharpen the news frame by emphasizing one side that is displayed. Behind it, decision making about which side is highlighted certainly involves the values and ideology of journalists involved in the process of producing news [8].

\subsection{Analysis of Social Cognition in the Suara Merdeka Newspaper}

Suara Merdeka newspaper is one of the oldest newspapers in Indonesia which had an initial mission to voice the voices of people who had just gained independence. Born in Semarang on February 11, 1950, Suara Merdeka was led by H. Hetami with a capital of IDR 250,000 obtained from his father's support, K.H Muhammad Idris. In its journey, Suara Merdeka does not always go through smooth roads and slabs. In addition to the production process which was still relatively complex at the time, another obstacle to the production process at that time was the availability of paper because, at certain times, the primary raw material of the newspaper was scarce on the market.

Basically, Hetami rejected affiliation politics in her media, Suara Merdeka. According to her, newspapers must be free from the interests of certain groups. The affiliation will only lead to bias in reporting to the public. That was the reason for choosing the motto "Independent, Objective, Without Prejudice" after publishing back at the beginning of the New Order. The motto replaces the old slogan, namely, "General Daily to Enhance the Resilience of the Indonesian Revolution". In general, the new motto aims to represent Suara Merdeka as a modern newspaper that is more free and different from other mass media that tend to be affiliated with certain groups or parties.

Following the era of the technological industry 4.0, Suara Merdeka also utilizes computer systems and internet access to manage data and information. Therefore, it is not surprising if, at one time, in three years, the development continues to increase tenfold because customers are serviced in such away. Not only that, but this newspaper also always improves the quality of the news.

This was confirmed by the results of an interview with the managing editor Suara Merdeka daily newspaper (Saroni Asikin) that conclusions could be made under the editorial policy that still leads to the basis of the vision and mission of the newspaper which then became the direction for newspaper journalists to go to the field looking for news material. 
The results of what is obtained are then taken into consideration for the editorial board to reduce the writing, choose a news source, determine the title of the news, placing a story and the like in each episode written. For this reason, the editorial board meets every morning to decide the main report to be released tomorrow morning. Based on this meeting, the editorial board will look for written materials, interviews, expert analysis field data, and so on. From these materials, the editor then compiles and selects to write news that reflects the editorial policy and Kompas vision and mission. Usually, a small meeting is also held in the afternoon before the deadline to evaluate or find additional information needed for writing.

From the results of the explanation of the production process, it can be concluded that the news production process at Suara Merdeka strives to be more balanced and objective. This is explained that to produce news, it is necessary to go through several critical stages starting from the editor, then the editor, and the reproduction held by the other responsible parties, until finally it is printed and distributed. In addition, the motto "Independent, Objective, Without Prejudice" is also used as a strong grip for the media crew at Suara Merdeka. This shows that Suara Merdeka strives to be balanced and objective in presenting corruption news, even though having an independent attitude is still difficult. This can be seen in the following fragment of data.

(1) Kasus Setnov yang menyita perhatian publik pun membuat pemerintah berencana membuat penjara khusus bagi para koruptor di pulau terpencil. "Sudah ada pemikiran ke sana untuk membuat lembaga pemasyarakatan khusus untuk koruptor, narkotika, dan khusus para teroris. Bahkan kami sudah memikirkan menggunakan pulau-pulau terpencil," kata Menko Polhukam Wiranto. Pemerintah menginginkan hukum ditegakkan secara lugas dan tanpa pandang bulu. Dia mengatakan, pelanggar hukum harus dijatuhi sanksi. [Setnov's case which caught the public's attention also made the government plan to create a particular prison for corruptors on a remote island. "There have been thoughts there to create a special prison for corruptors, narcotics, and specifically terrorists. We have even thought about using remote islands, "said Coordinating Minister for Political, Legal and Security Affairs Wiranto. The government wants the law to be enforced straightforwardly and indiscriminately. He said lawbreakers must be sanctioned.] (Napi Korupsi Dipindah ke Nusakambangan, Suara Merdeka, 18 Juni 2019) [Corruption Prisoner was Moved to Nusakambangan, Suara Merdeka, 18 June 2019]

(2) "Kalau sudah tidak bisa dinasihati maka OTT menjadi penting," kata Ganjar. Dikatakannya, di era terbuka saat ini sedang reformasi menuju pemerintahan bersih. Maka menurutnya jika ada yang berani menyalahinya maka itu nekat. "Di era yang sudah terbuka dan di era semua melakukan reformasi menuju pemerintahan bersih maka hanya orang yang bernyali tinggi alias nekat yang melakukan itu, " ucapnya. ["If it's not advisable, OTT is important," Ganjar said. He said, in the open era, there was currently reformation towards clean government. So according to him if anyone dares to violate it then it's reckless. "In an era that is already open and in an era of all reforming towards a clean government, only those who are brave and reckless do that," he said.] (Tamzil Terjerat Jual Beli Jabatan, Suara Merdeka, 27 Juli 2019) [Tamzil Entangled in Buy and Sell Position, Suara Merdeka, 27 July 2019]

Journalists showed the effort by inserting the opinions of legal figures to reinforce the statements that preceded them, namely Wiranto's opinion in the Setya Novanto case and Ganjar Pranowo's opinion in the corruption case of the Holy Regent, M. Tamzil. The journalist 
seemed to try to be balanced, but the balance was still seen to support the government and law enforcement in eradicating corruption.

\subsection{Analysis of Social Cognition in Republika Newspapers}

Since its establishment, the motto "Not Just Selling News" was used by Republika. Republika's ideology is the ideology of its owner, PT Abdi Bangsa, namely nationality, society, and Islam. Republika always strives to inspire social awareness in harmony with contemporary aspirations such as openness, pluralism, the sophistication of the information world by presenting Islamic content [9].

Previous differences in language style added to the business space and Republika's independence became stronger. With this collaboration, Republika continues to develop into a professional and mature national paper for the Muslim community, such as the vision it carries, "Making the Republika public daily a trusted Ummah newspaper and promoting universal values that are cool, tolerant, peaceful, intelligent, and professional, but has principles in its involvement in maintaining the unity of the nation and the interests of Muslims which is based on the understanding of Rahmatan Lil Alamin namely Grace to all beings in the world ".

Regarding the content of the media, Erick wants to advance a moderate appearance and reinforce entertaining writings in his daily paper, as in the following fragment.

(3) Wiranto menilai dengan keberadaan lapas di pulai terpencil akan meminimalisasi narapidana yang hendak kabur. "Kalau di pulau kan enggak bisa cuti, enggak bisa ngelayap. Masa mau berenang, kan enggak bisa. Maka sudah ada pikiran ke sana, semua tentu masih perlu rencana dan dukungan lain yang bisa mengarah ke sana," kata Wiranto. [Wiranto assessed that the presence of prisons in remote islands would minimize prisoners who wanted to escape. "If you cannot leave on the island, you cannot crawl. You don't want to swim, you can't. So there is already a thought to go there, of course, all of them still need plans and other support that can lead to it, "said Wiranto.] (Yasonna Tolak Pindahkan Napi Koruptor, Republika, 19 Juni 2019) [Yasonna Refuses to Move Corruptor Prisoners, Republika, June 19, 2019]

The fragment above shows how journalists in the Republika media pack news about the Setya Novanto case. Journalists tried to strengthen the news by including a direct statement from Wiranto as the Minister of Politics and Security and considered an experienced figure. However, the election of Wiranto's speech was not chosen by the journalists. The selected speech tends to be humorous but firm, as evidenced by the use of relaxed and satirical vocabulary.

In this case, it can indeed be concluded that in Republika, several cases have been acknowledged where capital owners try to intervene (intervene in the editorial) and want certain news or proposals. In some instances, if it turns out that the proposal is good and useful for us (editor), there is no problem. There is no problem for anyone giving the proposal, from the owners of capital, from directors, from outsiders. But if there is an intervention about an uncompromising reporting, there must be a debate first.

Editorial Republika is written alternately by one of the six editorial teams. This includes representatives from the chief editor and senior editor. The selection of opinion articles originating from outside the editorial members is structurally carried out by the managing editor, who, for that has entrusted a desk editor in the police force. According to his testimony, he selected about $80 \%$ of opinion articles published, around $20 \%$ was received on the 
recommendation of the managing editor or editor in chief. On the opinion page, there are two opinion articles, selected from about 30-40 posts per day. Sometimes the writings of editors also appear for specific themes. These opinion articles "automatically" reflect the direction of this newspaper, said the editor in question. "Our corporate culture, our readers are Muslims. We want to convey the goodness, universal values, humanity and democratic aspects of Islam, "said the Editor in Chief of Republika's Opinion.

\subsection{Analysis of Social Cognition in Kompas Newspapers}

Kompas newspaper was born when there was a history of "politics being commander in chief". At that time, political parties were recognized as the only social organization that could channel people's political aspirations. Therefore, the Kompas daily was present to be affiliated with the Catholic Party, which at that time was led by IJ Kasimo. After breaking away from affiliation with the Catholic Party, Kompas tried to become an independent media [10].

There are three discussion strategies carried out by Kompas if they have to explore a sensitive issue that develops in the community, for example, a problem that causes controversy in the community, namely (a) the Middle Road Model or Model Jalan Tengah (MJT), this model illustrates the Kompas strategy which sues indirectly, criticizes but is conveyed politely, impressed around and obscuring the message to be conveyed; (b) The Heavenly Wind Model or Model Angin Surga (MAS), in this model Kompas does not sue or question certain matters, but rather as an appeal and hope; (c) Guard Dog Model or Model Anjing Penjaga (MAP), this model is open and uses a bolder language [9].

Judging from its motto, Amanat Hati Nurani Rakyat, Kompas tries to show its alignments towards the people in terms of prioritizing the interests of the wider community. From this motto, it can be concluded that Kompas developed a mission in its reporting that addressed the public interest and not the interests of individuals or groups, as seen in the following fragment of data.

(4) Mencermati data KPK pada 2004 -2009, jenis korupsi yang paling banyak penyuapan (564 kasus), dilakukan anggota DPR/DPRD (247 kasus) dan swasta (238 kasus), paling banyak terjadi di kementerian/lembaga (321), dan berdasarkan wilayah ada di pemerintahan pusat. Dari data itu, seyogianya Jokowi-Ma'ruf fokus pada korupsi. Indonesia yang bersih dari korupsi belum terwujud. Padahal sejak tahun 1965, tepatnya 14 September 1965, Tajuk Rencana Kompas menulis, "Soal pentjoleng ekonomi sekarang ramai dibitjarakan lagi. Dibitjarakan lagi sebab sudah pernah bajhkan sering hal itu dijadikan bahan pembitjaraan. Jang ditunggu oleh rakjat sekarang bukan pembitjaraan lagi, tapi tindakan konkret: tangkap mereka, periksa, adili, hukum, gantung, tembak!" (Fokuslah pada Isu Korupsi, Kompas, 29 Juni 2019) [Observing the KPK data in 2004-2009, the most corrupt type is bribery (564 cases), carried out by members of DPR / DPRD (247 cases) and private sector (238 cases), most occurred in ministries/institutions (321), and based on the region in the central government. From this data, Jokowi-Ma'ruf should focus on corruption. Indonesia clean of corruption has not yet been realized. Even though since 1965, to be exact on September 14, 1965, Compass Editorials wrote, "The issue of economic development is now increasingly being pursued. Being pursued again because it has already been eradicated that it is often used as material for speaking. What the people are waiting for now is not speaking anymore, but concrete actions: arrest them, examine, try, prosecute, and hang, shoot!” (Focus on Corruption Issues, Kompas, 29 June 2019) 
In its reporting, Kompas strives to place the human side as the highest value, directing the focus of attention and goals towards transcendent values or overcoming group interests with its default formulation is "transcendental humanism" [9]. Kompas, in its journalistic work, has a vision and mission which are the foundation and steps of its steps, namely "an institution that gives enlightenment to the development of a democratic and dignified Indonesian society, and upholds the principles and values of humanity". Additionally, the traditional attachment does not just disappear, especially the ideology that forms the basis of its political policy.

Theoretically, Kompas declares itself to be an independent and objective newspaper in every news that it constructs. Kompas positioned itself as the mediator of various political streams in society. Kompas's vision is reflected in the motto "Mandate of the Conscience of the People," and its slogan "Open Eyes Open the Ear" as if it wants to represent itself as a distributor of the interests and conscience of the people. Although in the beginning, Kompas was affiliated with the Catholic Party, the newspaper's public vision must be open. The vision and attitude are not only in accordance with the beliefs of the leadership but also in accordance with the function of the press in Indonesia, which is to participate in developing and mutual understanding in society.

\subsection{Social Cognition Analysis in Jawa Pos Newspapers}

Jawa Pos Group is a company that houses 165 local and national newspapers, among which the most famous is Jawa Pos, and magazines, tabloids, and regional television. The majority of regional newspapers under the auspices of the Jawa Pos Group begin with "Radar", such as Radar Bandung, Radar Surabaya, Radar Solo, Radar Lampung, Radar, Radar Banjarmasin Banten, and so on.

In an effort to support the foundation for the print media industry, PT. Jawa Pos works hard to convey knowledge, current news, and technology to the wider community from various circles. This effort has been useful directly as a key holder to improve the national print media industry. By carrying out the vision of "Being a respected, exemplary respected and exemplary world print and online media company, Jawa Pos strives to maintain quality news with actual and reliable information. In the case of this corruption news, Jawa Pos positions itself as a media for voicing the aspirations of the people, as shown in the following fragment of news.

(5) Sebelumnya, Ditjenpas berkomitmen menempatkan napi-napi kasus korupsi kelas kakap di lapas super maximum security di Nusakambangan. Penempatan itu menjadi bagian dari penjeraan bagi koruptor. [Previously, Ditjenpas was committed to placing prisoners of high-class corruption cases in super maximum security prison in Nusakambangan. The placement was part of the detention for corruptors.] (KPK Ingin Setnov Dikirim ke Nusakambangan, Jawa Pos, 17 Juni 2019) [KPK Wants Setnov to be Sent to Nusakambangan, Jawa Pos, 17 June 2019]

(6) Nah, ulah Setnov yang berulang-ulang menyalahgunakan izin keluar lapas dinilai layak menjadi indikator penempatan napi ke Nusakambangan itu. [Well, the act of Setnov who repeatedly abuses the prison leave permit is deemed appropriate as an indicator of the placement of prisoners to Nusakambangan. (KPK Ingin Setnov Dikirim ke Nusakambangan, Jawa Pos, 17 Juni 2019) [KPK Wants Setnov to be Sent to Nusakambangan, Jawa Pos, 17 June 2019] 
From the data fragment above, it can be seen that there is a desire by the media to provide a deterrent effect on corruptors by positioning themselves as people who feel wronged by the corruptors. This presumption is supported by the statement of the existence of indicators of the placement of prisoners into Nusakambangan, one of which is by misuse of prison leave permits that are often carried out by high-class corruptors. The argument given by the media is because journalists hope for a change to a better level.

The process of producing content or news begins with the reporting of news sources by reporters and photographers in the field. In this case, official media journalists who have a press card carry out their functions in covering important news/events. Regarding their fields, reporters and photographers have been divided into a number of desks, such as government/city hall, legislative / DPRD desks, sports, grassroots, business economics, criminal law, education and culture, and so on. In their daily lives, these journalists cover their desks, except if there is a specific task to certain backup desks.

Reports and photographers report directly to the editorial secretary. All coverage will be listed as a record of events on that day. Then the news listing will be discussed by the editors led by the chief editor or the deputy chief editor in the afternoon. The listing meeting aims to determine the placement of news covered by reporters and photographers.

The selected news will be distributed to all available pages. News that has high journalistic value will be placed on the front or back cover page, both headlines and feature news. Likewise, each page contains news choices that are considered interesting by the editors.

After the listing meeting, the incoming news will go through an editing process by the editor. Like reporters and photographers, editors also have their respective duties. Among them is the main news desk on page 1, city page, regional page, business economy page, youth/zetizen page, thematic page, and sports page. Each editor usually has one to two pages. If more than two pages, then the editor's work will not be maximized. The aspect of accuracy, the element of news and photo appeal, the balance of heavy and light news locations, will not be fulfilled properly.

After the editor does the editing process, then the news will be layout by the page stylist (layouter) and graphic designer. News that has been arranged by the editor, layout will be done according to the scheme plan. The elements of design art are the responsibility of the layouter. How to make the page that contains news and photos which are good and interesting to read.

If the news has passed the layouting stage, then the file is directly sent to the preprinted section. Coordination with the printing press is usually carried out at night until midnight. Under certain conditions, this coordination can be carried out until after midnight. If you have entered the preprint, it will go through several stages, including checking the composition of the page with a pdf file, pressing, printing, print control, and finally, packing.

The flow of the newspaper production process will end with distribution to the existing marketing network. Since early morning, the expedition must distribute newspapers to several locations, including in urban areas and to some rural areas.

\section{Conclusion}

News construction or commonly known as framing a news text, is a privilege that is owned by each mass media. Therefore, the construction of news from Suara Merdeka, Republika, Kompas, and Jawa Pos media has some differences, although it does not rule out some similarities. The emphasis on several aspects can influence and sharpen the news frame by 
emphasizing one side that is displayed. Behind it, decision making about which side is highlighted certainly involves the values and ideology of the journalists involved in the process of producing news.

\section{REFERENCES}

[1] Subrata, "Penggunaan Bahasa Jurnalistik pada Media massa: Pendekatan Empiris" dalam Sudaryanto dan Sulistyo (eds.). Semarang: Citra Almamater, 1997.

[2] C. Juditha, "Objektivitas Berita Korupsi Pada Surat Kabar:(Analisis Isi Berita Pada Surat Kabar Kompas Periode Januari-Oktober 2012)," dalarn Jumal Penelit. Komunikasi, Inform. dan Media Massa-PEKOMMAS Makassar, vol. 16, no. 1, pp. 23-34, 2013.

[3] A. Y. Prasetyo, "Wajah Korupsi di Surat Kabar," Kompas.com, 2014. [Online]. Available:

https://nasional.kompas.com/read/2014/09/24/23000041/Wajah.Korupsi.di.Surat.Kaba r?page=all. [Accessed: 15-Mar-2019].

[4] Y. A. Darma, Analisis wacana kritis. Yrama Widya bekerja sama dengan Jurusan Pendididikan Bahasa dan Sastra ..., 2009.

[5] R. E. Asher and J. M. Y. Simpson, "The encyclopedia of language and linguistics," 1993.

[6] J. Renkema, Introduction to discourse studies. John Benjamins Publishing, 2004.

[7] Sudaryanto, Metode dan aneka teknik analisis bahasa: pengantar penelitian wahana kebudayaan secara linguistis. Duta Wacana University Press, 1993.

[8] A. Sobur, "Analisis teks media: suatu pengantar untuk analisis wacana, analisis semiotik, dan analisis framing," Bandung PT Remaja Rosdakarya, 2001.

[9] I. Hamad, Konstruksi realitas politik dalam media massa: Sebuah studi critical discourse analysis terhadap berita-berita politik. Yayasan Obor Indonesia, 2004.

[10] P. Santoso, "Suara Merdeka Jendela Mata Dunia," Suara Merdeka.com, 2007. [Online]. Available: https://www.suaramerdeka.com/smcetak/baca/47569/suaramerdeka-jendela-mata-dunia. 
